\title{
PENGGUNAAN KKBMM UNTUK MENINGKATKAN KETERAMPILAN MENULIS TEKS EKSEMPLUM PADA PESERTA DIDIK KELAS IX B SMP NEGERI 1 GABUS KABUPATEN GROBOGAN
}

\author{
SUHARTI \\ SMP Negeri 4 Satu Atap Ngaringan \\ e-mail: buharti123harti@gmail.com
}

\begin{abstract}
ABSTRAK
Tujuan penelitian ini adalah 1) mendeskripsikan proses pembelajaran menulis teks eksemplum dengan KKBMM pada peserta didik kelas IX B SMP Negeri 1 Gabus, Kabupaten Grobogan semester I tahun pelajaran 2015/2016; 2) mendeskripsikan peningkatan keterampilan menulis teks eksemplum dengan KKBMM pada peserta didik kelas IX B SMP Negeri 1 Gabus, Kabupaten Grobogan semester I tahun pelajaran 2015/2016; dan 3) mendeskripsikan perubahan sikap peserta didik kelas IX B SMP Negeri 1 Gabus, Kabupaten Grobogan semester I tahun pelajaran 2015/2016 dalam pembelajaran menulis teks eksemplum dengan KKBMM. Tempat penelitian di SMP Negeri 1 Gabus. Waktu penelitian yaitu bulan Agustus sampai dengan November 2015. Subjek penelitian adalah siswa kelas IX B SMP Negeri 1 Gabus tahun pelajaran 2015/2016. Pengumpulan data dengan teknik perekaman, penilaian diri, tes praktik, dan observasi. PTK dilaksanakan dalam 2 siklus. Proses pembelajaran dengan KKBMM dalam menulis teks eksemplum mengalami perkembangan. Minat belajar, keaktifan, semangat, keseriusan, dan respon peserta didik berkembang menjadi lebih baik. Persentase hasil angket pada siklus I sebesar $67 \%$ dan pada siklus II meningkat menjadi $80 \%$. Hasil belajar berupa keterampilan peserta didik dalam pembelajaran menulis teks eksemplum mengalami peningkatan. Pada prasiklus peserta didik yang tuntas belajar sebanyak 21 (58\%), siklus I sebanyak 27 (75\%), dan siklus II sebanyak 32 (89\%). Sikap peserta didik mengalami perubahan menjadi baik. Rata-rata nilai sikap menghayati ajaran agama yang dianut pada prasiklus sebesar 2,38 (cukup), pada siklus I menjadi 2,62 (baik), dan pada siklus II menjadi 3,10 (baik). Ratarata nilai sikap jujur pada prasiklus 2,26 (cukup), pada siklus I menjadi 2,49 (cukup), dan pada siklus II menjadi 3,14 (baik). Rata-rata nilai sikap percaya diri pada prasiklus sebesar 2,19 (cukup), pada siklus I menjadi 2,48 (cukup), dan pada siklus II menjadi 3,03 (baik). Pada siklus II persentase keberhasilan sikap menghargai ajaran agama yang dianut sebesar $94 \%$, sikap jujur sebesar $89 \%$, dan sikap percaya diri sebesar $83 \%$.
\end{abstract}

Kata kunci: KKBMM, keterampilan menulis, teks eksemplum

\section{ABSTRACT}

The aims of this study are 1) to describe the learning process of writing exemplum texts with KKBMM in class IX B students of SMP Negeri 1 Gabus, Grobogan Regency in the first semester of the 2015/2016 academic year; 2) describe the improvement of writing skills in exemplum text with KKBMM in class IX B students of SMP Negeri 1 Gabus, Grobogan Regency in the first semester of the 2015/2016 academic year; and 3) describe the change in attitude of students in class IX B of SMP Negeri 1 Gabus, Grobogan Regency in the first semester of the 2015/2016 academic year in learning to write exemplum texts with KKBMM. The research site is at SMP Negeri 1 Gabus. The time of the study was from August to November 2015. The research subjects were students of class IX B SMP Negeri 1 Gabus in the 2015/2016 academic year. Collecting data by recording techniques, self-assessment, practice tests, and observations. CAR is carried out in 2 cycles. The learning process with KKBMM in writing exemplum texts has developed. Interest in learning, activeness, enthusiasm, seriousness, and student responses develop for the better. The percentage of questionnaire results in the first cycle was $67 \%$ and in the second cycle increased to $80 \%$. Learning outcomes in the form of students' skills in learning to write exemplum texts have increased. In the pre-cycle students who finished studying were $21(58 \%)$, the first cycle was $27(75 \%)$, and the second cycle was 
$32(89 \%)$. The attitude of students has changed for the better. The average value of attitudes towards religious teachings adopted in the pre-cycle was 2.38 (enough), in the first cycle it was 2.62 (good), and in the second cycle it was 3.10 (good). The average value of honesty in the pre-cycle is 2.26 (enough), in the first cycle it becomes 2.49 (enough), and in the second cycle it becomes 3.14 (good). The average value of self-confidence in the pre-cycle was 2.19 (enough), in the first cycle it was 2.48 (enough), and in the second cycle it was 3.03 (good). In cycle II, the percentage of success in respecting religious teachings is $94 \%$, honesty is $89 \%$, and self-confidence is $83 \%$.

Keywords: KKBMM, writing skills, exemplum text

\section{PENDAHULUAN}

Dalam kurikulum 2013, bahasa Indonesia tidak hanya difungsikan sebagai alat komunikasi, tetapi juga sebagai sarana berpikir. Bahasa menjadi sarana untuk mengekspresikan gagasan. Sebuah gagasan yang utuh biasanya akan direalisasikan dalam bentuk teks. Teks dapat dimaknai sebagai ujaran atau tulisan bermakna yang memuat gagasan secara utuh. Ketika mengekspresikan gagasan dalam bentuk teks harus dipilih kata-kata dan strategi untuk menyajikan kata-kata tersebut agar gagasan dapat disampaikan dengan baik. Pilihan kata dan strategi penyajian kata-kata tersebut sangat ditentukan oleh tujuan dan situasi atau konteks. Oleh karena itu, masing-masing teks memiliki struktur isi, unsur kebahasaan, dan tujuan sosial yang berbeda.

Mahsun (2014:7) menjelaskan bahwa membelajarkan bahasa berbasis teks mampu menyajikan suatu materi dapat membangun struktur berpikir peserta didik. Hal itu disebabkan, satuan bahasa yang memiliki struktur berpikir lengkap sesuai konteks situasinya adalah teks. Berbeda jenis teks, berbeda strukturnya. Seorang peserta didik akan mampu memilih struktur berpikir dalam berbagai jenis untuk satu topik tergantung tujuan sosial yang hendak dicapai melalui penggunaan bahasa tersebut.

Menyusun teks baik secara lisan maupun tulisan merupakan salah satu kompetensi pada domain keterampilan. Pembelajaran menyusun atau menulis teks membutuhkan pemahaman dan keterampilan cukup kompleks. Peserta didik harus memiliki pemahaman terhadap masingmasing teks, baik dari struktur isi maupun unsur kebahasaan yang menjadi karakteristik dari masing-masing teks. Keterampilan peserta didik dalam mengembangkan topik, pengorganisasian gagasan, serta penguasaan kosakata juga berpengaruh terhadap hasil belajar peserta didik.

Keterampilan peserta didik kelas IX B SMP Negeri 1 Gabus dalam menulis teks eksemplum masih rendah. Peserta didik yang mencapai KKM 75 masih di bawah persentase keberhasilan belajar yang ditetapkan sekolah yaitu $80 \%$. Dari 36 peserta didik hanya terdapat 21 peserta didik yang memperoleh nilai sama dengan atau lebih dari KKM 75. Ini berarti keberhasilan pembelajaran menulis teks eksemplum hanya sebesar 58\%.

Selama proses pembelajaran, peserta didik juga terlihat kurang bergairah. Banyak peserta didik yang pasif dan kurang kreatif dalam mengerjakan tugas. Bahkan peserta didik merasa kesulitan dan tidak percaya diri untuk menuangkan ide-idenya sehingga sering terjadi menyontek hasil karya orang lain.

Untuk mengatasi permasalahan tersebut, guru perlu merancang skenario pembelajaran yang menggiring peserta didik lebih aktif, kreatif, dan percaya diri dalam pembelajaran. Penggunaan KKBMM diharapkan dapat mengatasi permasalahan dalam pembelajaran menyusun atau menulis teks eksemplum. Berdasarkan uraian tersebut, dalam penelitian diangkat judul penelitian Penggunaan KKBMM untuk Meningkatkan Keterampilan Menulis Teks Eksemplum pada Peserta Didik Kelas IX B SMP Negeri 1 Gabus, Kabupaten Grobogan Semester I Tahun Pelajaran 2015/2016. 


\section{METODE PENELITIAN}

Penelitian tindakan ini dilakukan dalam siklus-siklus. Siklus dikatakan berhasil apabila telah memenuhi atau melampaui indikator keberhasilan yang ditentukan. Apabila siklus belum memenuhi indikator keberhasilan, maka siklus dilanjutkan ke siklus berikutnya sampai indikator keberhasilan tercapai. Dalam pelaksanaannya, masing-masing siklus mengikuti tahap-tahap yang ada dalam penelitian tindakan kelas, yaitu tahap pertama perencanaan, tahap kedua implementasi atau pelaksanaan tindakan, tahap ketiga pengamatan atau observasi, dan tahap keempat refleksi. Empat tahap pokok dalam penelitian tindakan kelas tersebut dapat digambarkan dalam bagan berikut.

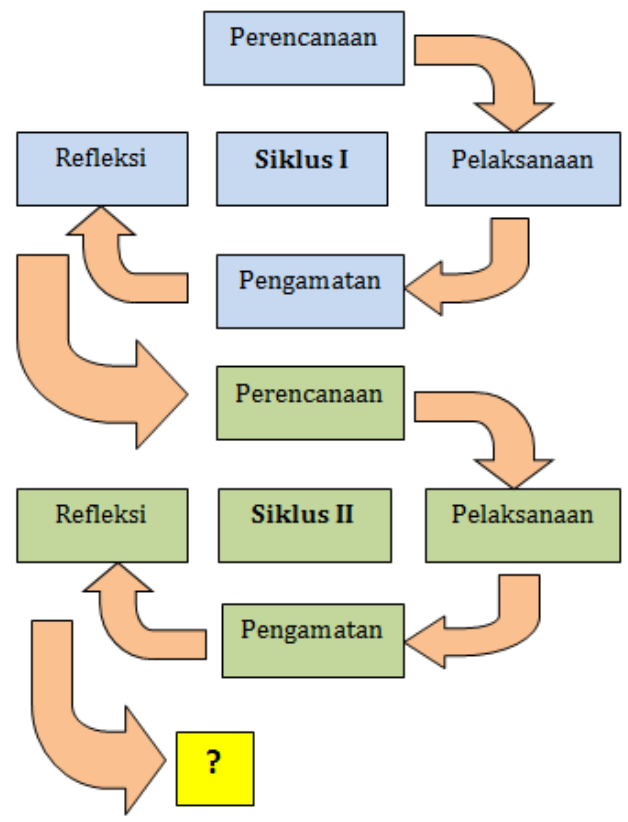

\section{Gambar 1. Skema Penelitian Tindakan Kelas}

Prosedur pelaksanaan tindakan dan implementasi tindakan siklus I dilaksanakan di kelas IX B SMP Negeri 1 Gabus semester I tahun pelajaran 2015/2016. Pembelajaran dilaksanakan dengan KKBMM. Penentuan anggota kelompok berdasarkan tempat duduk yang berdekatan. Hasil refleksi siklus I digunakan sebagai dasar untuk pelaksanaan tindakan pada siklus selanjutnya.

\section{HASIL DAN PEMBAHASAN}

\section{Hasil}

\section{Pra-Siklus}

\section{a. Keterampilan Menulis Teks Eksemplum}

Hasil tes keterampilan menulis teks eksemplum peserta didik kelas IX B SMP Negeri 1 Gabus semester 1 tahun pelajaran 2015/2016 sebelum dilaksanakan tindakan dapat dilihat dari tabel berikut ini.

Tabel 1. Analisis Hasil Ketrampilan Menulis Teks Pra Siklus

\begin{tabular}{|c|l|c|}
\hline No & \multicolumn{1}{|c|}{ Aspek } & Keterangan \\
\hline 1 & Nilai Terendah & 55 \\
\hline 2 & Nilai Tertinggi & 83 \\
\hline 3 & Nilai rata-rata & 70,92 \\
\hline 4 & Jumlah Peserta Didik & 36 \\
\hline 5 & Peserta Didik Behm Tuntas & 15 \\
\hline 6 & Peserta Didik Tuntas & 21 \\
\hline 7 & Persentase keberhasilan & $58 \%$ \\
\hline
\end{tabular}


Data pada tabel tersebut menunjukkan bahwa nilai terendah keterampilan menulis teks eksemplum peserta didik kelas IX B SMP Negeri 1 Gabus, Kabuapten Grobogan semester I tahun pelajaran 2015/2016 pada prasiklus adalah 55, sedangkan nilai tertinggi 83. Nilai ratarata keterampilan menulis teks eksemplum sebesar 70,92. Dari sejumlah 36 peserta didik, yang belum tuntas belajar sebanyak 15, sedangkan yang sudah tuntas sebanyak 21. Persentase keberhasilan menulis teks eksemplum pada kelas tersebut sebesar 58\%.

\section{b. Sikap Peserta didik}

Sikap peserta didik selama pembelajaran menulis teks eksemplum masih berada dalam kategori cukup. Hasil observasi terhadap sikap peserta didik pada sikap spiritual menghayati ajaran agama yang dianut, sosial percaya diri, dan sosial jujur selama pembelajaran pada prasiklus adalah sebagai berikut.

\begin{tabular}{|c|c|c|c|c|c|c|c|c|c|c|c|}
\hline \multirow{2}{*}{ No } & \multirow{2}{*}{ Kategori } & \multirow{2}{*}{ Rentang } & \multicolumn{3}{|c|}{$\begin{array}{c}\text { Menghayati } \\
\text { Ajaran Agama }\end{array}$} & \multicolumn{3}{|c|}{ Jujur } & \multicolumn{3}{|c|}{ Percaya Diri } \\
\hline & & & $\begin{array}{c}\text { Freku } \\
\text { nsi }\end{array}$ & $\begin{array}{l}\text { Perse } \\
\text { ntase }\end{array}$ & Rata2 & $\begin{array}{c}\text { Freku } \\
\text { nsi }\end{array}$ & $\begin{array}{c}\text { Perse } \\
\text { ntase }\end{array}$ & Rata2 & $\begin{array}{c}\text { Freku } \\
\text { nsi }\end{array}$ & $\begin{array}{c}\text { Perse } \\
\text { ntase }\end{array}$ & Rata2 \\
\hline 1 & Sangat baik & $3,50<\mathrm{x} \leq 4,00$ & 0 & $0 \%$ & \multirow{4}{*}{2,38} & 0 & $0 \%$ & \multirow{4}{*}{2,26} & 0 & $0 \%$ & \multirow{4}{*}{2,19} \\
\hline 2 & Baik & $2,50<x \leq 3,50$ & 15 & $42 \%$ & & 11 & $31 \%$ & & 9 & $25 \%$ & \\
\hline 3 & Cukup & $1,50<\mathrm{x} \leq 2,50$ & 21 & $58 \%$ & & 25 & $69 \%$ & & 25 & $69 \%$ & \\
\hline 4 & Kurang & $1,00<x \leq 1,50$ & 0 & $0 \%$ & & 0 & $0 \%$ & & 2 & $6 \%$ & \\
\hline \multicolumn{3}{|c|}{ Jumlah } & 36 & $100 \%$ & $\mathrm{C}$ & 36 & $100 \%$ & $\mathrm{C}$ & 36 & $100 \%$ & $\mathrm{C}$ \\
\hline \multicolumn{3}{|c|}{ Persentase keberhasilan } & \multicolumn{3}{|c|}{$42 \%$} & \multicolumn{3}{|c|}{$31 \%$} & \multicolumn{3}{|c|}{$25 \%$} \\
\hline
\end{tabular}

Data pada tabel tersebut menunjukkan nilai sikap peserta didik kelas IX B SMP Negeri 1 Gabus, Kabupaten Grobogan semester I tahun pelajaran 2015/2016 dalam pembelajaran menulis teks eksemplum. Sikap menghayati ajaran agama yang dianut peserta didik yang termasuk dalam kategori sangat baik belum ada, kategori baik sebanyak 15 peserta didik atau $42 \%$, kategori cukup sebanyak 21 peserta didik atau 78\%, dan kategori kurang tidak ada. Nilai rata-rata sikap menghayati ajaran agama yang dianut peserta didik adalah 2,31 termasuk dalam kategori cukup. Persentase keberhasilan sikap menghayati ajaran agama yang dianut sebesar $42 \%$.

Sikap jujur peserta didik yang termasuk dalam kategori sangat baik belum ada, kategori baik sebanyak 11 peserta didik atau 31\%, kategori cukup sebanyak 25 peserta didik atau 69\%, dan kategori kurang tidak ada. Nilai rata-rata sikap jujur peserta didik adalah 2,23 termasuk dalam kategori cukup. Persentase keberhasilan sikap jujur pada prasiklus sebesar $31 \%$.

Sikap percaya diri peserta didik kategori sangat baik belum ada, kategori baik sebanyak 9 peserta didik atau 25\%, kategori cukup sebanyak 25 peserta didik atau 69\%, dan kategori kurang sebanyak 2 peserta didik atau $6 \%$. Nilai rata-rata sikap percaya diri peserta didik adalah 2,19 termasuk dalam kategori cukup. Persentase keberhasilan sikap percaya diri sebesar $25 \%$.

\section{Siklus I}

\section{a. Peningkatan Hasil Belajar}

Hasil belajar tentang keterampilan peserta didik kelas IX B SMP Negeri 1 Gabus, Kabupaten Grobogan semester I tahun pelajaran 2015/2016 dalam menulis teks eksemplum dengan KKBMM dijelaskan melalui tabel berikut. 
Tabel 3. Analisis Hasil Ketrampilan Menulis Teks Siklus I

\begin{tabular}{|c|l|c|}
\hline No & \multicolumn{1}{|c|}{ Aspek } & Keterangan \\
\hline 1 & Nilai Terendah & 60 \\
\hline 2 & Nilai Tertinggi & 85 \\
\hline 3 & Nilai rata-rata & 74,94 \\
\hline 4 & Jumlah Peserta Didik & 36 \\
\hline 5 & Peserta Didik Belum Tuntas & 9 \\
\hline 6 & Peserta Didik Tuntas & 27 \\
\hline 7 & Persentase keberhasilan & $75 \%$ \\
\hline
\end{tabular}

Berdasarkan tabel tersebut dapat diketahui bahwa nilai terendah keterampilan menulis teks eksemplum peserta didik kelas IX B SMP Negeri 1 Gabus, Kabupaten Grobogan semester I tahun pelajaran 2015/2016 pada siklus I adalah 60, sedangkan nilai tertinggi 85. Nilai ratarata keterampilan menulis teks eksemplum sebesar 74,94. Dari sejumlah 36 peserta didik, yang belum tuntas belajar sebanyak 9, sedangkan yang sudah tuntas sebanyak 27. Persentase keberhasilan menulis teks eksemplum kelas IX B dalam menulis teks eksemplum sebesar $75 \%$.

\section{b. Perubahan Sikap Peserta Didik}

Observasi atau pengamatan pada siklus I dilakukan dengan mencatat sikap peserta didik selama pembelajaran menulis teks eksemplum dengan KKBMM. Observasi dilakukan oleh guru kolaborator. Sikap peserta didik yang menjadi fokus amatan adalah sikap spiritual menghayati ajaran agama yang dianut, sosial percaya diri, dan sosial jujur. Hasil observasi terhadap sikap peserta didik kelas IX B pada siklus I dijelaskan melalui tabel berikut.

Tabel 4. Analisis Hasil Observasi Sikap Peserta Didik Siklus I

\begin{tabular}{|c|c|c|c|c|c|c|c|c|c|c|c|}
\hline \multirow{2}{*}{ No } & \multirow{2}{*}{ Kategori } & \multirow{2}{*}{ Rentang } & \multicolumn{3}{|c|}{$\begin{array}{c}\text { Menghayati } \\
\text { Ajaran Agama }\end{array}$} & \multicolumn{3}{|c|}{ Jujur } & \multicolumn{3}{|c|}{ Percaya Diri } \\
\hline & & & $\begin{array}{c}\text { Freku } \\
\text { nsi }\end{array}$ & $\begin{array}{l}\text { Perse } \\
\text { ntase }\end{array}$ & Rata2 & $\begin{array}{c}\text { Freku } \\
\text { nsi }\end{array}$ & \begin{tabular}{|c|} 
Perse \\
ntase
\end{tabular} & Rata2 & $\begin{array}{c}\text { Freku } \\
\text { nsi }\end{array}$ & \begin{tabular}{|c|} 
Perse \\
ntase
\end{tabular} & Rate \\
\hline 1 & Sangat baik & $3,50<\mathrm{x} \leq 4,00$ & 1 & $3 \%$ & \multirow{4}{*}{2,62} & 0 & $0 \%$ & \multirow{4}{*}{2,49} & 0 & $0 \%$ & \multirow{4}{*}{2,48} \\
\hline 2 & Baik & $2,50<\mathrm{x} \leq 3,50$ & 23 & $64 \%$ & & 14 & $39 \%$ & & 15 & $42 \%$ & \\
\hline 3 & Cukup & $1,50<\mathrm{x} \leq 2,50$ & 12 & $33 \%$ & & 22 & $61 \%$ & & 21 & $58 \%$ & \\
\hline 4 & Kurang & $1,00<\mathrm{x} \leq 1,50$ & 0 & $0 \%$ & & 0 & $0 \%$ & & 0 & $0 \%$ & \\
\hline \multicolumn{3}{|c|}{ Jumlah } & 36 & $100 \%$ & B & 36 & $100 \%$ & $\mathrm{C}$ & 36 & $100 \%$ & $\mathrm{C}$ \\
\hline \multicolumn{3}{|c|}{ Persentase keberhasilan } & \multicolumn{3}{|c|}{$67 \%$} & \multicolumn{3}{|c|}{$53 \%$} & \multicolumn{3}{|c|}{$47 \%$} \\
\hline
\end{tabular}

Perubahan sikap peserta didik kelas IX B SMP Negeri 1 Gabus, Kabupaten Grobogan semester I tahun pelajaran 2015/2016 dalam pembelajaran menulis teks eksemplum dengan KKBMM pada siklus I dapat diketahui melalui tabel tersebut. Sikap menghayati ajaran agama yang dianut peserta didik yang termasuk dalam kategori sangat baik ada 1 peserta didik atau $3 \%$, kategori baik sebanyak 23 peserta didik atau 64\%, kategori cukup sebanyak 12 peserta didik atau 33\%, dan kategori kurang tidak ada. Nilai rata-rata sikap menghayati ajaran agama yang dianut peserta didik adalah 2,62 termasuk dalam kategori baik. Persentase keberhasilan sikap menghayati ajaran agama yang dianut sebesar $67 \%$.

Analisis hasil observasi sikap jujur peserta didik yang termasuk dalam kategori sangat baik belum ada, kategori baik sebanyak 14 peserta didik atau 39\%, kategori cukup sebanyak 22 peserta didik atau 61\%, dan kategori kurang tidak ada. Nilai rata-rata sikap jujur peserta didik adalah 2,49 termasuk dalam kategori cukup. Persentase keberhasilan sikap jujur sebesar 53\%. Sikap percaya diri peserta didik kategori sangat baik belum ada, kategori baik sebanyak 15 atau $42 \%$, kategori cukup sebanyak 21 peserta didik atau 58\%, dan kategori kurang tidak ada. Nilai rata-rata sikap percaya diri peserta didik adalah 2,48 termasuk dalam kategori cukup. Persentase keberhasilan sikap percaya diri pada siklus I sebesar $47 \%$. 


\section{Siklus II}

\section{a. Peningkatan Hasil Belajar}

Hasil belajar tentang keterampilan peserta didik kelas IX B SMP Negeri 1 Gabus, Kabupaten Grobogan semester I tahun pelajaran 2015/2016 dalam menulis teks eksemplum dengan KKBMM pada siklus II dijelaskan melalui tabel berikut.

\section{Tabel 5. Analisis Hasil Ketrampilan Menulis Teks Siklus II}

\begin{tabular}{|c|l|c|}
\hline No & \multicolumn{1}{|c|}{ Aspek } & Keterangan \\
\hline 1 & Nilai Terendah & 71 \\
\hline 2 & Nilai Tertinggi & 92 \\
\hline 3 & Nilai rata-rata & 81,89 \\
\hline 4 & Jumlah Peserta Didik & 36 \\
\hline 5 & Peserta Didik Behm Tuntas & 4 \\
\hline 6 & Peserta Didik Tuntas & 32 \\
\hline 7 & Persentase keberhasilan & $89 \%$ \\
\hline
\end{tabular}

Berdasarkan tabel tersebut dapat diketahui bahwa nilai terendah keterampilan menulis teks eksemplum peserta didik kelas IX B SMP Negeri 1 Gabus, Kabupaten Grobogan semester I tahun pelajaran 2015/2016 pada siklus II adalah 71, sedangkan nilai tertinggi 92. Nilai ratarata keterampilan menulis teks eksemplum sebesar 81,89. Dari sejumlah 36 peserta didik, yang belum tuntas belajar sebanyak 4, sedangkan yang sudah tuntas sebanyak 32. Persentase keberhasilan menulis teks eksemplum kelas IX B dalam menulis teks eksemplum pada siklus II sebesar $89 \%$.

\section{b. Perubahan Sikap Peserta Didik}

Sikap peserta didik selama proses pembelajaran menulis teks eksemplum dengan KKBMM pada siklus II dicatat dalam lembar observasi. Sikap peserta didik yang menjadi fokus amatan masih sama dengan siklus II yaitu sikap spiritual menghayati ajaran agama yang dianut, sosial percaya diri, dan sosial jujur. Analisis hasil observasi terhadap sikap peserta didik kelas IX B pada siklus II dijelaskan melalui tabel berikut.

Tabel 6. Analisis Hasil Observasi Sikap Peserta Didik Siklus I

\begin{tabular}{|c|c|c|c|c|c|c|c|c|c|c|c|}
\hline \multirow{2}{*}{ No } & \multirow{2}{*}{ Kategori } & \multirow{2}{*}{ Rentang } & \multicolumn{3}{|c|}{$\begin{array}{c}\text { Menghayati } \\
\text { Ajaran Agama }\end{array}$} & \multicolumn{3}{|c|}{ Jujur } & \multicolumn{3}{|c|}{ Percaya Diri } \\
\hline & & & $\begin{array}{c}\text { Freku } \\
\text { nsi }\end{array}$ & $\begin{array}{l}\text { Perse } \\
\text { ntase }\end{array}$ & Rata2 & $\begin{array}{c}\text { Freku } \\
\text { nsi }\end{array}$ & $\begin{array}{l}\text { Perse } \\
\text { ntase }\end{array}$ & Rata2 & $\begin{array}{c}\text { Freku } \\
\text { nsi }\end{array}$ & $\begin{array}{l}\text { Perse } \\
\text { ntase }\end{array}$ & Rata2 \\
\hline 1 & Sangat baik & $3,50<\mathrm{x} \leq 4,00$ & 7 & $19 \%$ & \multirow{4}{*}{3,10} & 10 & $28 \%$ & \multirow{4}{*}{3,14} & 8 & $22 \%$ & \multirow{4}{*}{3,03} \\
\hline 2 & Baik & $2,50<x \leq 3,50$ & 27 & $75 \%$ & & 22 & $61 \%$ & & 22 & $61 \%$ & \\
\hline 3 & Cukup & $1,50<x \leq 2,50$ & 2 & $6 \%$ & & 4 & $11 \%$ & & 6 & $17 \%$ & \\
\hline 4 & Kurang & $1,00<x \leq 1,50$ & 0 & $0 \%$ & & 0 & $0 \%$ & & 0 & $0 \%$ & \\
\hline \multicolumn{3}{|c|}{ Jumlah } & 36 & $100 \%$ & B & 36 & $100 \%$ & B & 36 & $100 \%$ & B \\
\hline \multicolumn{3}{|c|}{ Persentase keberhasilan } & \multicolumn{3}{|c|}{$94 \%$} & \multicolumn{3}{|c|}{$89 \%$} & \multicolumn{3}{|c|}{$83 \%$} \\
\hline
\end{tabular}

Data pada tabel tersebut menunjukkan sikap peserta didik SMP Negeri 1 Gabus, Kabupaten Grobogan semester I tahun pelajaran 2015/2016 dalam pembelajaran menulis teks eksemplum dengan KKBMM pada siklus II. Sikap menghayati ajaran agama yang dianut peserta didik yang termasuk dalam kategori sangat baik sebanyak 7 peserta didik atau 19\%, kategori baik sebanyak 27 peserta didik atau 75\%, kategori cukup sebanyak 2 peserta didik atau $6 \%$, dan kategori kurang tidak ada. Nilai rata-rata sikap menghayati ajaran agama yang dianut 
peserta didik adalah 3,10 termasuk dalam kategori baik. Persentase keberhasilan sikap menghayati ajaran agama yang dianut pada siklus II sebesar $67 \%$.

Analisis hasil observasi sikap jujur peserta didik yang termasuk dalam kategori sangat baik sebanyak 10 peserta didik atau 28\%, kategori baik sebanyak 22 peserta didik atau $61 \%$, kategori cukup sebanyak 4 peserta didik atau $11 \%$, dan kategori kurang tidak ada. Nilai ratarata sikap jujur peserta didik adalah 3,14 termasuk dalam kategori baik. Persentase keberhasilan sikap jujur pada siklus II sebesar $89 \%$.

Sikap percaya diri peserta didik kategori sangat baik sebanyak 8 peserta didik atau $22 \%$, kategori baik sebanyak 22 peserta didik atau $61 \%$, kategori cukup sebanyak 6 peserta didik atau $17 \%$, dan kategori kurang tidak ada. Nilai rata-rata sikap percaya diri peserta didik adalah 3,03 termasuk dalam kategori baik. Persentase keberhasilan sikap percaya diri pada siklus II sebesar $83 \%$.

\section{Pembahasan}

\section{a. Peningkatan Hasil Belajar}

Peningkatan hasil belajar berupa keterampilan menulis teks eksemplum dari prasiklus (sebelum menggunakan KKBMM) sampai siklus II (dengan KKBMM) pada peserta didik kelas IX B SMP Negeri 1 Gabus, Kabupaten Grobogan semester I tahun pelajaran 2015/2016 dapat diketahui pada tabel berikut.

Tabel 7. Perbandingan Pra Siklus, Siklus I, dan Siklus II

\begin{tabular}{|c|l|c|c|c|}
\hline No & \multicolumn{1}{|c|}{ As pek } & Prasiklus & Siklus I & Siklus II \\
\hline 1 & Nilai Terendah & 55 & 60 & 71 \\
\hline 2 & Nilai Tertinggi & 83 & 85 & 92 \\
\hline 3 & Nilai rata-rata & 70,92 & 74,94 & 81,89 \\
\hline 4 & Jumlah Peserta Didik & 36 & 36 & 36 \\
\hline 5 & Peserta Didik Behum Tuntas & 15 & 9 & 4 \\
\hline 6 & Peserta Didik Tuntas & 21 & 27 & 32 \\
\hline 7 & Persentase Keberhasilan & $58 \%$ & $75 \%$ & $89 \%$ \\
\hline 8 & Besarnya Peningkatan & & $17 \%$ & $14 \%$ \\
\hline
\end{tabular}

Berdasarkan tabel tersebut, dapat diketahui peningkatan rata-rata nilai keterampilan menulis teks eksemplum peserta didik kelas IX B SMP Negeri 1 Gabus, Kabupaten Grobogan semester I tahun pelajaran 2015/2016 sejak prasiklus sampai dengan siklus II. Pada prasiklus nilai terendah peserta didik adalah 55, pada siklus I meningkat menjadi 60, dan meningkat lagi pada siklus II menjadi 71. Nilai tertinggi pada prasiklus adalah 83, pada siklus I meningkat menjadi 85, dan siklus II menjadi 92. Nilai rata-rata pada prasiklus adalah 70,92. Setelah dilakukan tindakan dengan KKBMM pada siklus I nilai rata-rata meningkat menjadi 74,94 dan nilai rata-rata pada siklus II meningkat lagi menjadi 81,89 . Jumlah peserta didik yang tuntas belajar pada prasiklus sebanyak 21, pada siklus I meningkat menjadi 27 peserta didik, dan siklus II meningkat lagi menjadi 32. Persentase keberhasilan pada prasiklus sebesar 58\%, pada siklus I meningkat menjadi $75 \%$, dan pada siklus II meningkat lagi menjadi $89 \%$. Besarnya peningkatan keberhasilan dari prasiklus ke siklus I sebesar $17 \%$ dan dari siklus I ke siklus II sebesar $14 \%$.

Peningkatan hasil belajar menulis peserta didik kelas IX B SMP Negeri 1 Gabus, Kabupaten Grobogan semester I tahun pelajaran 2015/2016 tersebut juga dapat diketahui melalui grafik berikut ini. 
घumlah Peserta Didik Tuntas a Rata-rata $\quad$ Persentase Keberhasilan



Gambar 2. Grafik Perbandingan Pra Siklus, Siklus I, dan Siklus II

Berdasarkan grafik tersebut dapat diketahui bahwa pada tahap prasiklus jumlah peserta didik yang tuntas belajar sebanyak 21 dengan nilai rata-rata 70,92 dan persentase keberhasilan sebesar 58\%. Pada tahap siklus I peserta didik yang tuntas belajar sebanyak 27 dengan nilai rata-rata 74,94 dan persentase keberhasilan sebesar 75\%. Pada tahap siklus II peserta didik yang tuntas belajar sebanyak 32 dengan nilai rata-rata 81,89 dan persentase keberhasilan sebesar 89\%. Dari grafik tersebut dapat disimpulkan adanya peningkatan hasil belajar menulis teks eksemplum dengan KKBMM bagi peserta didik kelas IX B SMP Negeri 1 Gabus Tahun Pelajaran 2015/2016. Besarnya peningkatan keberhasilan dari prasiklus ke siklus I sebesar 17\% dan dari siklus I ke siklus II sebesar 14\%.

\section{KESIMPULAN}

1. Proses pembelajaran dapat berkembang menjadi baik setelah dilaksanakan tindakan dengan KKBMM dalam pembelajaran menulis teks eksemplum. Minat belajar, keaktifan, semangat, keseriusan, dan respon peserta didik kelas IX B SMP Negeri 1 Gabus, Kabupaten Grobogan semester I tahun pelajaran 2015/2016 berkembang menjadi lebih baik. Persentase hasil angket pada siklus I sebesar $67 \%$ dan pada siklus II meningkat menjadi $80 \%$.

2. Hasil belajar berupa keterampilan peserta didik dalam pembelajaran menulis teks eksemplum dengan KKBMM pada kelas IX B SMP Negeri 1 Gabus, Kabupaten Grobogan semester I tahun pelajaran 2015/2016 meningkat. Pada prasiklus peserta didik yang tuntas belajar sebanyak 21 atau sebesar 58\%, pada siklus I sebanyak 27 atau sebesar 75\%, dan pada siklus II sebanyak 32 atau sebesar $89 \%$.

3. Sikap peserta didik kelas IX B SMP Negeri 1 Gabus, Kabupaten Grobogan semester I tahun pelajaran 2015/2016 dalam proses pembelajaran menulis teks eksemplum dengan KKBMM mengalami perubahan menjadi baik. Rata-rata nilai sikap peserta didik dalam menghayati ajaran agama yang

\section{DAFTAR PUSTAKA}

Amin, Moh. (2011). Panduan Praktis Penelitian Tindakan Kelas untuk Penilaian Angka Kredit Guru. Grobogan: Inspirasi.

Buzan, Tony. (2008). Buku Pintar Mind Map. Jakarta: Gramedia Pustaka Utama.

Edward. C. (2009). Mind Mapping untuk Anak Sehat dan Cerdas. Yogyakarta: Sakti.

Mahsun. (2014). Teks dalam Pembelajaran Bahasa Indonesia Kurikulum 2013. Jakarta: Raja Grafindo Persada.

Pranowo. (2014). Teori Belajar Bahasa untuk Guru Bahasa dan Mahasiswa Jurusan Bahasa. Yogyakarta: Pustaka Pelajar.

Priyatni, Endah Tri. (2015). Desain Pembelajaran Bahasa Indonesia dalam Kurikulum 2013. Jakarta: Bumi Aksara. 
Rastavara, Djoened. (2015). Teks Eksemplum dan Strukturnya. http://rajailmupengetahuan.blogspot.co.id/2015/08/teks-eksemplum-dan-strukturnya.html. Diunduh tanggal 8 Agustus 2015.

Sudjana, Nana. (2005). Penilaian Hasil Proses Belajar Mengajar. Bandung: Remaja Rosdakarya. 